\title{
PENGARUH KUALITAS PELAYANAN TERHADAP KEPUASAN KONSUMEN PADA PERUSAHAAN MASTER PIECE KARAOKE
}

\author{
Yudi Irawan Abi 1)
}

1) Department of Management, Faculty of Economic, Universitas Dehasen Bengkulu

\section{Email: ${ }^{1)}$ yudiirawanabi@unived.ac.id}

How to Cite :

Abi, Y.I. (2020). PENGARUH KUALITAS PELAYANAN TERHADAP KEPUASAN KONSUMEN PADA PERUSAHAAN MASTER PIECE KARAOKE DI KOTA BENGKULU. EKOMBIS REVIEW: Jurnal IImiah Ekonomi Dan Bisnis, 3(1).

DOI: https://doi.org/10.37676/ekombis.v9i1.1223

\section{ARTICLE HISTORY}

Received [16 November 2020] Revised [07 December 2020] Accepted [27 January 2021]

\section{KEYWORDS}

Tangible, reliability, Responsiveness, Assurance, Empathy and Customer satisfaction

This is an open access article under the $C C-B Y-S A$ license

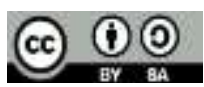

\section{ABSTRAK}

Mengetahui pengaruh tangible, reliability, responsiveness, assurance dan empathy kualitas pelayanan terhadap kepuasan konsumen Master Piece Karaoke di Bengkulu. Teknik pengambilan sampel dalam penelitian ini menggunakan teknik purposive sampling dan pengumpulan data dilakukan dengan menyebarkan kuesioner kepada responden. Kuesioner dibagikan kepada 100 responden Master Piece Karaoke di Bengkulu. Alat analisis yang digunakan adalah regresi linier berganda dengan menggunakan SPSS 16. Pengujian hipotesis menggunakan uji T. Hasil penelitian menunjukkan bahwa secara parsial variabel tangible, reliability, responsiveness, assurance dan empathy berpengaruh signifikan terhadap kepuasan konsumen Karaoke Master Piece di Bengkulu. Berdasarkan analisis diketahui nilai koefisien determinasi Adjusted R Square sebesar 0,477 yang berarti 47,7\% variabel kepuasan konsumen dipengaruhi oleh variabel kualitas pelayanan.

\section{ABSTRACT}

The purpose of this study was to determine the effect of tangible, reliability, responsiveness, assurance and empathy of service quality to consumer satisfaction of Master Piece Karaoke in Bengkulu. The sampling technique in this study using purposive sampling techniques and data collection is done by distributing questionnaires to the respondents. The questionaires were distributed to the 100 respondent of Master Piece Karaoke in Bengkulu. The analysis tool used is multiple linear regression using SPSS 16. Hypothesis testing using the $T$ test. Result shows that partially, tangible, reliability, responsiveness, assurance and empathy variables has significant effect on consumer 
satisfaction of Master Piece Karaoke in Bengkulu. Based on the analysis of known coefficient of determination value of Adjusted $R$ Square is 0.477 , this means $47,7 \%$ variable consumer satisfaction is influenced by variables service quality.

\section{PENDAHULUAN}

Saat ini bisnis jasa sudah menjadi trend usaha para pebisnis di Indonesia. Ini ditandai oleh banyaknya perusahaan-perusahaan yang bergerak bidang jasa di Indonesia. Kotler (2012) mendefinisikan jasa sebagai setiap tindakan atau kegiatan yang ditawarkan oleh satu pihak ke pihak lain, pada dasarnya bersifat intangible (tidak berwujud fisik) dan tidak mengakibatkan kepemilikan apapun. Proses produksinya mungkin tidak dikaitkan dengan suatu produk fisik. Kondisi seperti ini menuntut setiap perusahaan untuk menciptakan keunggulan kompetitif bisnisnya terutama perusahaan jasa dimana produk yang dihasilkan hanya mampu dirasakan bukan untuk dimiliki atau dilihat melainkan agar mampu bersaing secara berkesinambungan dengan perusahaan-perusahaan lain yang berkecimpung dalam bidang yang sama. Saat ini kualitas pelayanan telah tegas diakui sebagai senjata strategis yang penting untuk mengamankan keunggulan kompetitif dalam pasar dan sering dianggap sebagai sebagai prasyarat bagi setiap perusahaan jasa untuk bertahan hidup. Selain itu, kualitas pelayanan yang kuat memfasilitasi pengembangan dan pemeliharaan hubungan jangka panjang dengan konsumen, yang merupakan hal penting dalam lingkungan bisnis yang kompetitif saat ini (Camarero, 2007). Perusahaan yang ingin berkembang dan mendapatkan keunggulan kompetitif harus dapat memberikan produk berupa barang atau jasa yang berkualitas dan pelayanan yang baik kepada para konsumen, sehingga akan muncul kepuasan dalam benak pelanggan dan diharapkan akan membawa dampak positif bagi perusahaan.

Perusahaan penyedia barang atau jasa dapat mengambil langkah-langkah untuk meminimalkan tingkat ketidakpuasan pasca pembelian dengan memberikan kepuasan yang lebih tinggi baik dari produk atau jasa maupun pelayanan yang diberikan Tjiptono (2009). Untuk mendapatkan kepuasan yang lebih tinggi pada saat konsumen melakukan pembelian terhadap produk maupun jasa, maka hal ini biasanya terkait dengan faktor-faktor pelayanan yang mempengaruhi kepuasan konsumen pasca pembelian produk maupun jasa tersebut. Dalam membeli suatu produk atau jasa, seorang konsumen mungkin mendeteksi adanya suatu kekurangan. Konsumen tidak menginginkan produk atau jasa yang tidak memenuhi standar mutu. Apa yang menentukan konsumen akan puas atau tidak puas tehadap suatu pembelian baik itu produk maupun jasa Lupiyoadi (2013). Kepuasan merupakan perasaan senang atau kecewa seseorang yang timbul karena membandingkan kinerja yang dipersepsikan produk terhadap harapan mereka (Kotler 2012). Konsumen akan merasa tidak puas jika suatu produk atau jasa tidak sesuai harapan yang diinginkan, konsumen akan merasa puas jika suatu produk atau jasa sesuai atau seimbang dengan harapan yang diinginkan, dan konsumen akan merasa sangat puas jika suatu produk atau jasa melebihi harapan yang mereka inginkan.

Saat ini hiburan sudah menjadi sesuatu hal yang penting dan salah satu kebutuhan yang tidak dapat dipisahkan dari kehidupan masyarakat terutama 
masyarakat yang tinggal diperkotaan, dengan tujuan untuk menghilangkan stres akibat rasa lelah dan kejenuhan karena rutinitas yang dilakukan setiap harinya. Akhir-akhir ini semakin banyak berdirinya tempat hiburan khususnya tempat karaoke. Para pebisnis ini berasal dari kalangan masyarakat biasa hingga para artis pun ikut berlomba-lomba mendirikan usaha karaoke. Khususnya di Kota Bengkulu saat ini sudah banyak tempat hiburan karaoke yang berdiri. Dalam kesempatan ini, dimanfaatkan oleh suatu perusahaan yang bergerak dibidang jasa hiburan karaoke yaitu Master Piece Karaoke. Melihat kondisi tersebut, maka peneliti tertarik untuk meneliti lebih lanjut seberapa besar pengaruh faktor-faktor pelayanan seperti: bukti langsung (tangible), kehandalan (reliability), daya tanggap (responsiveness), jaminan (assurance), serta kepedulian (empathy) dalam memenuhi kepuasan konsumen. Oleh karena itu, agar tercapai tingkat kepuasan konsumen yang diharapkan Master Piece Karaoke maka perlu dilakukan penelitian tentang : "Analisis Pengaruh Kualitas Pelayanan Terhadap Kepuasan Konsumen pada Perusahaan Jasa Master Piece di Kota Bengkulu.

\section{LANDASAN TEORI}

\section{Kepuasan Konsumen}

Dewasa ini perhatian terhadap kepuasan maupun ketidakpuasan konsumen telah semakin besar karena pada dasarnya tujuan dari suatu perusahaan adalah untuk menciptakan rasa puas pada konsumen. Semakin tinggi tingkat kepuasan konsumen, maka akan mendatangkan keuntungan yang semakin besar bagi perusahaan, karena konsumen akan melakukan pembelian ulang terhadap produk perusahaan. Namun, apabila tingkat kepuasan yang dirasakan pelanggan kecil, maka terdapat kemungkinan bahwa konsumen tersebut akan pindah ke produk pesaing.

Kepuasan merupakan perasaan senang atau kecewa seseorang yang timbul karena membandingkan kinerja yang dipersepsikan produk terhadap harapan mereka (Kotler 2012). Sedangkan menurut Tjiptono (2011) kepuasan atau ketidakpuasan pelanggan adalah respon konsumen terhadap suatu produk atau jasa yang dirasakan saat sebelum pemakaiannya dan yang dirasakan setelah pemakaiannya. Kepuasan konsumen terhadap suatu produk ataupun jasa, sebenarnya sesuatu yang sulit untuk didapat jika perusahaan jasa atau industri tersebut tidak benar-benar mengerti apa yang diharapkan oleh konsumen. Untuk produk atau layanan dengan kualitas yang sama, dapat memberikan tingkat kepuasan yang berbeda-beda bagi konsumen yang berbeda. Oleh karena itu, suatu perusahaan harus selalu memperhatikan kualitas produk maupun pelayanan yang diberikan kepada konsumen. Kepuasan konsumen merupakan respons konsumen terhadap ketidaksesuaian antara tingkat kepentingan sebelumnya dan kinerja aktual yang dirasakannya setelah pemakaian. Kepuasan konsumen dipengaruhi oleh persepsi kualitas jasa, kualitas produk, harga dan faktor-faktor yang bersifat pribadi serta yang bersifat situasi sesaat (Rangkuti 2009).

\section{Kualitas Layanan}

Modernitas dengan kemajuan teknologi akan mengakibatkan persaingan yang sangat ketat untuk memperoleh dan mempertahankan konsumen. Kualitas pelayanan menjadi suatu keharusan yang harus dilakukan perusahaan supaya mampu bertahan dan tetap mendapat kepercayaan konsumen. Pola konsumsi dan gaya hidup konsumen menuntut perusahaan mampu memberikan pelayanan yang berkualitas. 
Keberhasilan perusahaan dalam memberikan pelayanan yang berkualitas dapat ditentukan dengan pendekatan service quality. Menurut Kotler (2012) service quality adalah seberapa jauh perbedaan antara harapan dan kenyataan para konsumen atas layanan yang mereka terima. Service Quality dapat diketahui dengan cara membandingkan persepsi konsumen atas layanan yang benar-benar mereka terima dengan layanan sesungguhnya yang mereka harapkan. Kualitas pelayanan menjadi hal utama yang diperhatikan serius oleh perusahaan, yang melibatkan seluruh sumber daya yang dimiliki perusahaan. Definisi mutu jasa berpusat pada pemenuhan kebutuhan dan keinginan konsumen serta ketepatan penyampaian untuk mengimbangi harapan konsumen.

Menurut Tjiptono (2011) kualitas pelayanan adalah upaya pemenuhan kebutuhan dan keinginan konsumen serta ketepatan penyampaiannya dalam memenuhi harapan konsumen. Apabila jasa yang diterima sesuai dengan yang diharapkan, maka kualitas jasa dipersepsikan baik dan memuaskan. Jika jasa yang diterima melampaui harapan konsumen, maka kualitas jasa dipersepsikan ideal. Sebaliknya jika jasa yang diterima lebih rendah dari pada yang diharapkan, maka kualitas jasa dianggap buruk. Mengacu pada pengertian kualitas layanan tersebut maka konsep kualitas layanan adalah suatu daya tanggap dan realitas dari jasa yang diberikan perusahaan. Kualitas pelayanan harus dimulai dari kebutuhan konsumen dan berakhir pada persepsi konsumen. Hal ini berarti bahwa kualitas yang baik bukanlah berdasarkan persepsi penyediaan jasa, melainkan berdasarkan persepsi konsumen.

Lupiyoadi (2013) mengemukakan bahwa kualitas pelayanan berpengaruh terhadap kepuasan pelanggan, dimana pelayanan yang baik berakibat lebih besar terhadap kepuasan konsumen. Walaupun pelayanan/jasa adalah suatu barang yang tidak berwujud, namun pelayanan dapat dinilai berdasarkan pengalaman dan penalaran seseorang. Kualitas pelayanan dapat mempengaruhi kepuasan konsumen karena terjadinya interaksi antara konsumen dengan pihak perusahaan. Sesuai dengan konsep kepuasan konsumen, bahwa kepuasan konsumen dapat tercapai bila kinerja atau hasil yang dirasakan sesuai dengan harapan konsumen. Jadi, baik atau tidaknya pelayanan yang diberikan oleh perusahaan, sangatlah mempengaruhi kepuasan konsumen.

Terdapat lima dimensi kualitas pelayanan menurut Tjiptono (2009), dimensi kualitas pelayanan, dapat disimpulkan beberapa dimensi yang kredibel yaitu dengan memenuhi syarat agar sebuah pelayanan memungkinkan untuk menimbulkan kepuasan konsumen. Adapun dimensi-dimensi tersebut yaitu: tangible atau bukti nyata, reliability atau kehandalan, responsiveness atau ketanggapan, assurance atau jaminan, empathy atau kepedulian. 


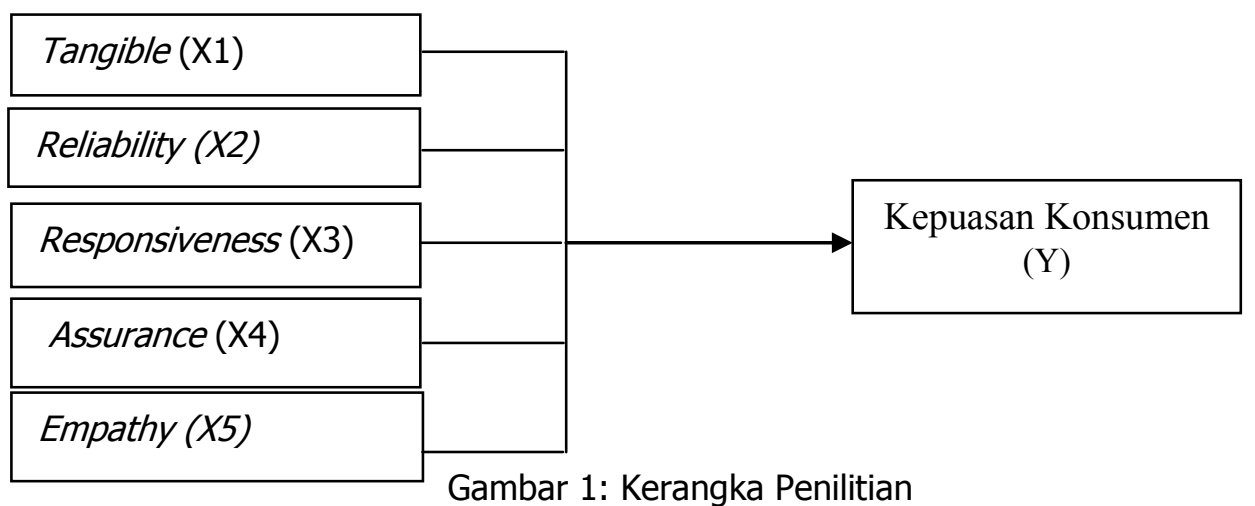

H1: Bukti fisik/tangible berpengaruh positif terhadap kepuasan konsumen.

H2: Kehandalan/reliability berpengaruh positif terhadap kepuasan konsumen.

H3: Daya tanggap/responsiveness berpengaruh positif terhadap kepuasan konsumen.

H4: Jaminan/Assurance berpengaruh positif terhadap kepuasan konsumen

H5: Empathy/kepedulian berpengaruh positif terhadap kepuasan konsumen.

\section{METODE PENELITIAN}

Sesuai dengan tujuan penelitian ini, untuk mengetahui dan menganalisis pengaruh kualitas pelayanan terhadap kepuasan konsumen perusahaan jasa Master Piece Karaoke. Penelitian ini dilakukan dengan pendekatan deskriptif serta kuantitatif dan jenis penelitiannya studi kasus ini didukung dengan teknik survei. Jenis penelitian ini adalah penelitian deskriptif kuantitatif yaitu penelitian yang bertujuan untuk memaparkan dan menjelaskan sifat suatu keadaan yang sedang berlangsung pada saat penelitian dilakukan. Metode yang akan digunakan untuk pengambilan sampel adalah metode non-probability sampling. Dalam metode ini, elemen populasi dipilih atas dasar ketersediaan atau karena pertimbangan pribadi bahwa mereka dapat mewakili populasi (Ferdinand, 2014). Adapun cara pengambilan sampel yang akan digunakan adalah purposive sampling, yaitu pengambilan sampel dalarn hal yang terbatas pada jenis orang tertentu yang dapat memberikan informasi yang diinginkan, yakni konsumen/pengguna Master Piece Karaoke di kota Bengkulu. Sampel yang diambil dalam penelitian ini adalah sebesar 100 responden. Metode analisis yang digunakan dalam penelitian ini adalah analisis regresi berganda (multiple regression analysis). Analisis regresi berganda digunakan untuk menganalisis pengaruh variabel bebas yang terdiri dari tangible/bukti fisik (X1), reliability/keandalan (X2), responsiveness/daya tanggap (X3), assurance/jaminan (X4), emphaty/empati (X5) terhadap variabel terikat yaitu kepuasaan konsumen $(\mathrm{Y})$.

\section{HASIL DAN PEMBAHASAN}

Metode yang digunakan untuk menganalisis pengaruh dari berbagai variabel independen terhadap satu variabel dependen. Analisis regresi berganda digunakan untuk mengetahui seberapa besar pengaruh variabel bebas (Independent) yaitu: Tangible (X1), Reliability (X2), Responsiveness (X3), Assurance (X4) dan Emphaty (X5) terhadap variabel terikat (dependen) Kepuasan Konsumen ( $\mathrm{Y}$ ). 
Tabel 1. Analisis Regresi Linier Berganda

\begin{tabular}{|c|c|c|c|c|c|}
\hline \multirow[b]{2}{*}{ Model } & \multicolumn{2}{|c|}{\begin{tabular}{|l} 
Unstandardiz \\
ed Coefficients
\end{tabular}} & \multirow{2}{*}{\begin{tabular}{|c|}
\multicolumn{1}{|c|}{ Standar } \\
dized \\
Coefficients \\
Beta \\
\end{tabular}} & \multirow[b]{2}{*}{$\mathrm{T}$} & \multirow[b]{2}{*}{ Sig. } \\
\hline & 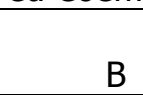 & Error ${ }^{\text {Std. }}$ & & & \\
\hline (Constant) & 3,257 & 1,635 & & 1,992 &, 049 \\
\hline Tangible & ,355 & ,113 & ,306 & 3,132 &, 002 \\
\hline Reliability & ,307 &, 126 & ,241 & 2,446 &, 016 \\
\hline Responsivene & 209 & 101 & 174 & 2,059 & ,042 \\
\hline Assurance & , 192 & ,065 & ,232 & 2,970 & ,004 \\
\hline Emphaty &, 318 & ,152 &, 182 & 2,093 &, 039 \\
\hline
\end{tabular}

Sumber: Hasil Penelitian 2020, diolah

Uji hipotesis digunakan untuk mengetahui apakah hipotesis dapat diterima atau ditolak dengan menggunakan program SPSS versi 23, maka diperoleh hasil sebagai berikut :

Berdasarkan hasil uji statistik yang telah dilakukan diperoleh Hasil pengujian variabel bukti nyata (tangib/e) menunjukkan nilai t hitung $=3,132$ dengan nilai signifikansi sebesar $0,002<0,05$, bahwa pada variabel tangible/bukti nyata terdapat pengaruh yang positif dan signifikan terhadap kepuasan konsumen dalam menggunakan jasa Master Piece Karaoke. Hal ini mengindikasikan bahwa responden merasa puas dengan bentuk fisik dari pelayanan Master Piece Karaoke. Teori yang mendukung penelitian dikemukakan oleh Lupiyoadi (2013) yang menyatakan bahwa, "Kualitas pelayanan dari bukti fisik berupa penggunaan alat, ketersediaan perlengkapan yang terpenuhi dan kemampuan individu untuk memberikan suatu kualitas pelayanan sangat berpengaruh dalam memuaskan konsumen". Hasil ini sesuai dengan pendapat Tjiptono (2011) bahwa "bukti fisik berkenaan dengan daya tarik fasilitas fisik, perlengkapan, dan material yang digunakan perusahaan, serta penampilan karyawan." Dengan kata lain jika perusahaan dapat memberikan mendapat respon positif sehingga menimbulkan kepuasan pelanggan. Hal ini menunjukkan bahwa bukti fisik menjadi variabel yang mempengaruhi meningkat atau menurunnya kepuasan. Oleh karena itu, bukti fisik seperti penampilan karyawan, bangunan, fasilitas serta peralatan yang diberikan oleh Master Piece Karaoke menjadi salah satu unsur dalam menentukan kepuasan pelanggan.

Berdasarkan hasil uji statistik yang telah dilakukan diketahui bahwa Hasil pengujian variabel kehandalan (reliability) menunjukkan nilai t hitung $=2,446$ dengan nilai signifikansi sebesar ,016 < 0,05, bahwa pada variabel reliability/kehandalan terdapat pengaruh yang positif dan signifikan terhadap kepuasan konsumen dalam menggunakan jasa Master Piece Karaoke. Dengan adanya karyawan yang cepat dalam melayani konsumen dan proses menggunakan jasa yang tidak berbelit-belit, tentunya akan semakin membuat konsumen merasa kualitas pelayanan yang diberikan Master Piece Karaoke semakin memuaskan. Hal ini sejalan dengan penelitian yang dilakukan oleh Lupiyoadi, (2013) yang menyatakan keandalan mempunyai pengaruh yang signifikan terhadap kepuasan konsumen. Menurut A.Parasuraman (2001) keandalan merupakan "Kemampuan perusahaan untuk memberikan pelayanan yang akurat sejak pertama kali tanpa membuat kesalahan apapun dan menyampaikan jasanya sesuai dengan waktu yang disepakati". Jadi layanan yang akurat sangat berpengaruh 
terhadap kepuasan pelanggan termasuk memiliki karyawan-karyawan yang handal dibidangnya, maka para pelanggan akan merasa puas terhadap perusahaan. (Kotler 2012).

Berdasarkan hasil uji statistik yang telah dilakukan diperoleh variabel daya tanggap (responsiveness) menunjukkan nilai t hitung $=2,059$ dengan nilai signifikansi sebesar 0,042 < 0,05, bahwa pada variabel responsiveness/daya tanggap terdapat pengaruh yang positif dan signifikan terhadap kepuasan konsumen dalam menggunakan jasa Master Piece Karaoke. Responsiveness/daya tanggap merupakan salah satu hal penting yang harus dimiliki setiap perusahaan jasa terutama karyawan perusahaan karena dengan memiliki daya tanggap yang baik, akan membuat konsumen merasa diberikan perhatian yang serius saat mereka membutuhkan sesuatu. Setelah apa yang diinginkan konsumen terpenuhi dengan baik, maka konsumen akan merasa puas dengan kinerja serta pelayanan yang diberikan karyawan dan perusahaan. Teori yang mendukung dikemukakan oleh Lupiyoadi (2013) bahwa, "Suatu layanan jasa banyak melibatkan adanya tingkat tanggap dari suatu konsumen untuk memberikan suatu pelayanan yang dapat memuaskan konsumen. Hal ini sejalan dengan penelitian yang dilakukan oleh (Panjaitan \& Yuliati. 2016) yang menyatakan daya tanggap mempunyai pengaruh yang signifikan terhadap kepuasan konsumen. Penelitian yang dilakukan oleh Hasan (2009) menyebutkan bahwa variable responsiveness berpengaruh positif dan signifikan terhadap kepuasan pelanggan.

Berdasarkan hasil uji statistik yang telah dilakukan diperoleh hasil pengujian variabel jaminan (assurance) menunjukkan nilai $t$ hitung $=2,970$ dengan nilai signifikansi sebesar 0,004 $<0,05$, bahwa pada variabel assurance/jaminan terdapat pengaruh yang positif dan signifikan terhadap kepuasan konsumen dalam menggunakan jasa Master Piece Karaoke. Assurance/jaminan adalah kemampuan perusahaan untuk menimbulkan rasa percaya dan keyakinan konsumen untuk tetap menggunakan jasa perusahaan mereka. Assurance/jaminan tidak hanya tentang bagaimana perusahaan membuat konsumen tetap percaya dan yakin untuk menggunakan jasa mereka, tapi assurance/jaminan juga meliputi keamanan konsumen saat menggunakan jasa mereka. Dengan adanya jaminan yang baik dari perusahaan terhadap konsumen, tentunya hal ini akan meningkatkan kepuasan konsumen dalam menggunakan jasa perusahaan tersebut. Hal ini sejalan dengan penelitian yang dilakukan oleh Lupiyoadi (2013) yang menyatakan jaminan tidak mempunyai pengaruh yang signifikan terhadap kepuasan konsumen. Teori yang mendukung dikemukakan oleh Tjiptono (2009) menyatakan bahwa, "Dasar-dasar dari suatu pelayanan jasa dalam menjalin suatu kemitraan adalah keyakinan yang ditumbuhkan kepada konsumen, sehingga loyalitas yang diberikan sangat mempengaruhi tingkat kepuasan konsumen.

Berdasarkan hasil uji statistik yang telah dilakukan diperoleh pengujian variabel kepedulian (empathy) menunjukkan nilai $\mathrm{t}$ hitung $=2,093$ dengan nilai signifikansi sebesar 0,039<0,05, bahwa pada variabel empathy/kepedulian terdapat pengaruh yang positif dan signifikan terhadap kepuasan konsumen dalam menggunakan jasa Master Piece Karaoke. Empathy/kepedulian dapat berupa jalinan komunikasi yang baik antara perusahaan dengan konsumen, memahami apa yang dibutuhkan konsumen, dan kemudahan bagi konsumen dalam memberikan masukan atau saran kepada perusahaan. Apabila konsumen memberikan penilaian yang baik bagi perusahaan mengenai kepedulian mereka terhadap konsumen, maka hal tersebut akan berdampak sangat baik bagi kepuasan konsumen. Dan hal ini akan membuat konsumen berniat 
kembali menggunakan jasa perusahaan tersebut. Konsep dan teori yang mendukung yaitu Tjiptono (2011) menyatakan bahwa, "Empati dalam kualitas pelayanan merupakan aspek keseriusan, pembinaan, penyuluhan dan memberikan image mengenai pola pengembangan pelayanan yang harus dipenuhi agar memberikan impact kepada kepuasan konsumen" Hal ini sejalan dengan penelitian yang dilakukan oleh Lupiyoadi, (2013) yang menyatakan empati tidak mempunyai pengaruh yang signifikan terhadap kepuasan konsumen

\section{KESIMPULAN DAN SARAN}

\section{Kesimpulan}

Berdasarkan hasil analisis yang telah disimpulkan bahwa Master Piece Karaoke harus bisa mempertahankan kualitas pelayanan yang sudah dianggap baik oleh sebagian besar konsumennya. Akan tetapi Master Piece Karaoke tetap harus meningkatkan kinerjanya lebih baik lagi agar kualitas pelayanan yang diberikan bisa selalu memberikan kepuasan kepada konsumen. Dengan kualitas pelayanan yang baik maka konsumen akan puas pada saat menggunakan Master Piece Karaoke, sehingga dapat meningkatkan citra positif di mata tamu konsumen dan pada akhirnya akan tercipta kepuasan konsumen yang bagus pada Master Piece Karaoke.

\section{Saran}

Pihak Master Piece Karaoke bisa lebih menerima atau membuka diri untuk konsumen dalam memberikan keluhan atau pendapat mereka. Master Piece Karaoke juga dirasa perlu untuk memonitor kepuasan pelanggan secara berkala melalui pelaksanaan survei dalam mengantisipasi perubahan-perubahan yang mungkin terjadi di masa depan. Hasil pelaksanaan survei secara berkala menjadi tolok ukur bagi Master Piece Karaoke dalam mengembangkan serta membina hubungan dengan pelangganpelanggannya. 


\section{DAFTAR PUSTAKA}

A, Parasuraman. (2001). The Behaviorial Consequenses of Service Quality, Jurnal of Marketing, Vol 60.

Camarero, Claudio. 2007. Relationship Orientation Or Service Quality. What Is The Trigger Of Performance In Financial And Insurance Services

Ferdinand. 2014. Metode Penelitian Manajemen. Semarang: Seri Pustaka Kunci.

Hasan, 2009, Marketing, Yogyakarta : MedPress (Anggota IKAPI)

Kotler, Philip. 2012. Manajemen Pemasaran. Edisi 13. Jakarta: Erlangga.

Lupiyoadi, Rambat. 2013. Manajemen Pemasaran Jasa (Praktek dan Teori). Jakarta: Salemba.

Panjaitan \& Yuliati. 2016. Pengaruh Kualitas Pelayanan Terhadap Kepuasan Pelanggan pada JNE Cabang Bandung. Derema Jurnal Manajemen Vol. 11 No. 2

Rangkuti, Freddy. 2009. Strategi Promosi yang Kreatif dan Analisis Kasus Integrated Marketing Communication. Jakarta: PT. Gramedia Pustaka Utama.

Sarwono. 2006. Metode Penelitian Kuantitatif dan Kualitatif. Yogyakarta :Graha Ilm

Sekaran, Uma (2006). Research Methods For Business: A Skill Building Aproach, New York-USA: John Wiley and Sons, Inc

Sugiyono. 2010. Metode Penelitian Bisnis. Bandung: Alfabeta.

Tjiptono, Fandy. 2009. Service Marketing: Esensi dan Aplikasi. Yogyakarta: Marknesis.

Tjiptono, Fandy. 2011. Pemasaran Jasa. Malang: Bayumedia Publishing. 